\title{
Tingkat Pemahaman Akuntansi Mahasiswa Jurusan Akuntansi Fakultas Ekonomi Universitas Lancang Kuning Dari Sudut Pandang Kecerdasan Spiritual
}

\author{
RENI FARWITAWATI \\ Universitas Lancang Kuning \\ Jln. Yos Sudarso KM 08 Rumbai Pekanbaru \\ E-mail : reni@unilak.ac.id
}

\begin{abstract}
This research supported by the accounting education too dominated by the nature of maskulinitasnya focusing on rationality (intellect) that disregarded various points of view that should be integrated as a whole for civilization. This study attempts to assess the accounting students about using intelligence spiritual perspective. In order to explore understanding students from this perspective intelligence, phenomenology used as methodology, with the interpretive as an umbrella research. Understanding and awareness about students with intelligence spiritual be conducted in depth. The result of this research is that college students are are already able to understand accounting of spiritual intelligence to each, but students still fastened with characters (either to character educator and students and has long been rooted system on education accounting. By the presence of these constraints, put forward the idea that it takes an to able to seek a change in accounting education so balance by integrating various points of view as a whole.
\end{abstract}

Keywords: Understanding Accounting, Spiritual Quotient, Accounting Education

Untuk mengasah ilmunya, selama ini peserta didik hanya terpaku pada kecerdasan intelektualnya (Triyuwono, 2010). Hal senada diungkapkan oleh Kamayanti (2012), menurut mereka salah satu ciri maskulinitas pada pendidikan akuntansi adalah terlalu besarnya fokus pada rasionalitas. Hal ini terjadi mungkin karena tuntutan dari lingkungan sosialnya, sehingga dengan sendirinya membentuk mahasiswa sebagai peserta didik memahami ilmu yang dipelajarinya dari sudut pandang intelektualnya saja.

Dampak pendidikan yang hanya berpusat pada kecerdasan akal saja dapat dilihat dari perilaku dan sifat mahasiswa. Terkadang ketika mengambil sebuah keputusan, terlalu mempertimbangkan berapa materi yang akan dikorbankan dan apa benefit yang akan diterima dari keputusan tersebut. Hal ini didukung oleh temuan Mulawarman (2006, 2007, Triyuwono (2010) dan dalam Kamayanti (2012) yang mengatakan bahwa ini akan berwujud pada calon-calon akuntan yang bercirikan rasionalis, antroposentris/ egois, apatis, tidak peka keadaan sekitar (impersonality), objektif dan kehilangan nilai-nilai spiritualitas. Secara umum, sifat yang dihasilkan adalah individualis, materialistis dan terpaku pada pemikiran yang logis. Menurut Shariati dalam Agustian (2005:16), manusia adalah makhluk dua dimensional yang membutuhkan penyelerasan kebutuhan akan kepentingan dunia dan akhirat. Oleh sebab itu, manusia harus memiliki konsep duniawi atau kepekaan emosi dan intelegensia yang baik (EQ plus IQ) dan penting pula penguasaan ruhiyah vertikal atau Spiritual Quotient (SQ).

Selama ini banyak berkembang dalam masyarakat sebuah pandangan stereotip, dikotomisasi antara dunia dan akhirat. Dikotomisasi antara unsur-unsur kebendaan dan unsur agama, antara unsur kasat mata dan tak kasat mata. Materialisme versus orientasi nilai-nilai Ilahiyah semata. Mereka yang cenderung memilih keberhasilan di alam "vertikal" cenderung berpikir bahwa kesuksesan dunia justru adalah sesuatu yang bisa 
"dinisbikan" atau sesuatu yang bisa demikian mudahnya "dimarjinalkan". Hasilnya, mereka unggul dalam kekhusyu"ean dzikir dan kekhitmatan berkontemplasi, dalam kata lain menjadi seorang petapa, namun menjadi kalah dalam kancah ekonomi, ilmu pengetahuan, sosial, politik dan perdagangan di alam "horizontal". Begitupun sebaliknya yang berpijak hanya pada alam kebendaan, kekuatan berpikirnya tak pernah diimbangi oleh kekuatan dzikir, berujung pada egoisme dan materialistis. Sehingga wajar menurut penulis jika Ary Ginanjar Agustian menyatakan dalam bukunya bahwa "Realitas kebendaan yang masih membelenggu hati, tidak memudahkan baginya untuk berpijak pada alam fitrahnya (zero mind)".

Sebenarnya konsep kecerdasan yang menyeluruh sudah menjadi cita-cita mulia bangsa kita, terbukti dalam UndangUndang No. 20 Tahun 2003 tentang tujuan Pendidikan Nasional Bab II Pasal 3 yang berbunyi: Pendidikan Nasional bertujuan mengembangkan kemampuan dan membentuk watak serta peradaban bangsa yang bermartabat dalam rangka mencerdaskan bangsa, bertujuan untuk berkembangnya potensi peserta didik agar menjadi manusia yang beriman dan bertaqwa kepada Tuhan YME, berakhlak mulia, sehat, berilmu, cakap, kreatif, mandiri dan menjadi warga Negara yang demokratis serta bertanggung jawab.

Dengan adanya Undang-Undang tersebut, maka dari waktu ke waktu bidang pendidikan yang didasarkan kepada pengembangan moral serta etika yang mengedepankan keikutsertaan penerapan religiuitas yang tidak hanya sebatas penyampaian ilmu, haruslah menjadi prioritas dan menjadi orientasi untuk kemudian diusahakan penyediaan sarana dan prasarananya sehingga akan meningkatkan potensi spiritual dan membentuk peserta didik agar menjadi manusia yang beriman dan bertakwa kepada Tuhan Yang Maha Esa dan berakhlak mulia. Akhlak mulia mencakup etika, budi pekerti, dan moral sebagai perwujudan dari suatu pendidikan akuntansi yang mengarah kepada basis keseimbangan (La'lang, 2010).

Sebenarnya isi dari UndangUndang tersebut sudah sarat akan makna keseimbangan tersebut, tetapi kenyataannya pendidikan di Indonesia, termasuk pendidikan akuntansi yang berkembang selama ini, terlalu menekankan arti penting nilai akademik, kecerdasan otak atau IQ saja. Mulai dari tingkat sekolah dasar sampai ke bangku kuliah, jarang sekali ditemukan pendidikan tentang kecerdasan emosi yang mengajarkan tentang kecerdasan emosi yang mengajarkan tentang: integritas; kejujuran; komitmen; visi; kreatifitas; ketahanan mental; kebijaksanaan; keadilan; prinsip kepercayaan; penguasaan diri atau sinergi, padahal justru inilah hal yang terpenting. Mungkin kita bisa melihat hasil dari bentukan karakter dan kualitas sumber daya manusia era 2000 yang patut dipertanyakan, yang berbuntut pada krisis ekonomi yang berkepanjangan. Hal ini ditandai dan dimulai dengan krisis moral atau buta hati yang terjadi di mana-mana. Mengapa hal ini terjadi? Karena menurut Mulawarman (2008) sistem pendidikan saat ini telah lepas dari realitas masyarakat Indonesia dan dibawa langsung dari "dunia lain" (baca: Barat) yang memiliki nilai-nilai Indonesia sendiri tanpa kodifikasi dan penyesuaian yang signifikan. Akuntansi merupakan produk yang dibangun dari nilai-nilai masyarakat dimana akuntansi dan sistem akuntansi dikembangkan (lihat misalnya Hines 1989; Morgan 1989; Mulawarman 2012 dan banyak lainnya). Akuntansi dan sistem pendidikan akuntansi menurut Mulawarman (2008) memang membawa values (nilai-nilai) "sekularisasi" yang memiliki ciri utama self-interest, menekankan bottom line laba dan hanya mengakui realitas yang tercandra (materialistik) (Mulawarman, 2012). 
Pendidikan akuntansi semacam ini tentu membawa konsekuensi pada praktik akuntansi. Hal yang menarik telah dipaparkan oleh Irianto mengenai praktikpraktik akuntansi yang berjalan selama ini tidak sedikit menimbulkan permasalahan. Irianto (2003, 2006) dalam La'lang (2010) memaparkan dengan seksama hal ini. Sebut saja skandal kebangkrutan Enron yang turut menjadi skandal terbesar dalam sejarah akuntansi. Dalam proses pengusutan sebabsebab kebangkrutan itu Enron dicurigai telah melakukan praktek window dressing. Manajemen Enron telah menggelembungkan (mark up) pendapatannya US\$ 600 juta, dan menyembunyikan utangnya sejumlah US\$ 1,2 miliar. Hal ini tentunya hanya bisa dilakukan oleh orang-orang yang memiliki keahlian dengan trik-trik manipulasi yang tinggi dan tentu saja orang-orang ini merupakan orang bayaran dari mulai analis keuangan, para penasihat hukum, dan auditornya. Ini disebabkan karena adanya unsur kebohongan yang dilakukan pada sebuah sistem terbuka, terjadi pelanggaran terhadap kode etik berbagai profesi seperti akuntan, pengacara, dan lain sebagainya, dimana segelintir professional tersebut serakah dengan memanfaatkan ketidaktahuan dan keawaman banyak orang, serta praktek persekongkolan tingkat tinggi. Ini tentu menunjukkan bahwa manusia sebagai pelaku sudah tidak lagi berada dalam koridor akhlak serta moralitas sebagai kehendak Tuhan sehingga hidup berdasarkan "takut akan Tuhan" mulai memudar sejalan dengan masa modernisme yang kian menjulang.

Diakui atau tidak, selama bertahuntahun dunia akuntansi sebagai salah satu aspek pendidikan, seakan terpasung di persimpangan jalan, tersisih di antara hiruk-pikuk dan hingar bingar ambisi penguasa yang ingin mengejar pertumbuhan dan daya saing bangsa. Pendidikan akuntansi seolah tidak diarahkan untuk memanusiakan manusia secara "utuh" dan "paripurna", tetapi lebih diorientasikan pada hal-hal yang bersifat materialistis, ekonomis dan teknokratis, kering dari sentuhan nilai-nilai moral, kemanusiaan dan budi pekerti. Pendidikan akuntansi lebih mementingkan kecerdasan intelektual, akal, dan penalaran, tanpa diimbangi dengan intensifnya pengembangan kecerdasan hati, perasaan, emosi dan spiritual. Akibatnya, apresiasi output pendidikan terhadap keagungan nilai humanistik, keluhuran budi, dan budi nurani, menjadi nihil (La'lang, 2010).

Saya memperhatikan proses belajar-mengajar di kelas, memang mahasiswa "disodorkan" oleh berbagai jenis teori, dan tentunya semua itu terpaku pada textbook sehingga "menghipnotis" mahasiswa untuk mempunyai pemikiran yang cenderung kaku. Penelitian Davidson dan Baldwin (2005) dalam Setiawan dan Kamayanti (2012) menyimpulkan bahwa di AS, praktik pendidikan akuntansi $100 \%$ bertumpu pada accounting textbooks. Ditambah lagi kondisi bahwa tipe perkuliahan lebih disukai; situasi di mana dosen menganggap pengetahuan yang disampaikan adalah "kado/ hadiah (gift)" kepada mahasiswa (Setiawan dan Kamayanti, 2012). Mayoritas mahasiswa memahami akuntansi adalah suatu cara agar entitas dapat menghimpun kekayaan sebesar-besarnya, beranggapan bahwa yang lebih banyak bekerja berarti yang lebih banyak mendapatkan hasilnya, tanpa memikirkan pihak-pihak yang dirugikan atas tindakan yang telah dilakukan. Setiawan dan Kamayanti (2012) mengutip dari Powell and Dimaggio (1997:63), Max Weber menyatakan bahwa rasionalisme menjadi penjara (iron cage) yang mengekang unsur kemanusiaan. Terbukti pernyataan Max Weber terjadi dalam pendidikan akuntansi, berdampak pada pemahaman mahasiswa terhadap akuntansi. Segala sesuatu diukur dengan satuan uang, sehingga menghasilkan sifat materialistis. Bahkan ada pula mahasiswa yang memahami bahwa akuntansi merupakan sebuah alat politis yang menjadikan perantara untuk 
memaksimalisasi kepentingan pihak-pihak tertentu. Sebagaimana dikutip dari Triyuwono (2009), angka-angka adalah salah satu bentuk logosentrisme dari akuntansi mainstream. Bahkan menurut pandangan Hines (1989) tanpa angka adalah suatu hal yang sangat mustahil bagi akuntansi, dan implikasinya adalah tanpa akuntansi kita tidak dapat menggambarkan keadaan perusahaan. Logosentrisme ini terutama dicirikan dengan: pertama, pola berpikir oposisi biner (dualistik, dikhotomis) yang hierarkis, dan kedua ilmu pengetahuan positivistis yang mekanis, linier dan bebas-nilai. Dengan demikian dapat dimengerti bahwa logosentrisme sebagai produk modernisme mempunyai ciri "penunggalan" melalui universalitas. Konsekuensi dari penunggalan ini adalah bahwa "sang lain" (the others) yang berada di luar dirinya akan selalu disubordinasikan, dieliminasikan, dan jika mungkin harus "dibunuh". Dari gambaran diatas dapat ditarik suatu kesimpulan sederhana bahwa akuntansi hanyalah sebuah "alat" bantu untuk mengkalkulasi angka-angka (baca: uang) yang nantinya berakhir pada pengambilan keputusan ekonomi.

Setiap manusia mempunyai suara hati yang sejatinya menyuarakan kebenaran dalam bertingkah laku, tetapi suara hati tersebut bertentangan dengan mindset yang telah mengakar dan karena tuntutan keadaan. Agustian (2005:40) melanjutkan, kebenaran sejati, sebenarnya terletak pada suara hati yang bersumber dari spiritual center ini, yang tidak bisa ditipu oleh siapa pun, atau oleh apa pun, termasuk diri kita sendiri. Mata hati ini dapat mengungkap kebenaran hakiki yang tak tampak di hadapan mata. Bahkan kata ahli sufi Islam Jalaludin Rumi, "Mata hati punya kemampuan 70 kali lebih besar untuk melihat kebenaran daripada dua indera penglihatan".

Menurut Cooper (1998) dalam Agustian (2005:40), "Hati mengaktifkan nilai-nilai kita yang paling dalam, mengubahnya dari sesuatu yang kita pikir menjadi sesuatu yang kita jalani. Hati tahu hal-hal yang tidak, atau tidak dapat, di ketahui oleh pikiran. Hati adalah sumber keberanian dan semangat, integritas dan komitmen. Hati adalah sumber energi dan perasaan mendalam yang menuntut kita belajar, menciptakan kerjasama, memimpin dan melayani."

$$
\text { Pendidikan agama yang }
$$

semestinya dapat diandalkan dan diharapkan bisa memberi solusi bagi permasalahan hidup saat ini, ternyata lebih diartikan atau dipahami sebagai ajaran fiqih. Tidak untuk dipahami dan dimaknai secara mendalam, dan lebih condong pada pemisahan kehidupan dunia dan akhirat, tanpa ada kesadaran diri untuk mengintegrasikan keduanya dalam bertingkah laku. Sejak saya duduk di bangku Sekolah Dasar, sampai Sekolah Menengah Pertama, memang pelajaran Agama menjadi mata pelajaran yang wajib, tetapi hanya bentuk hafalan, tanpa dipahami maknanya secara mendalam. Unsur intuisi, rasa, emosi serta kesadaran Ketuhanan (spiritualitas) menjadi sesuatu yang terpinggirkan, termarginalkan (untuk tidak mengatakan dihilangkan sepenuhnya) (Setiawan dan Kamayanti, 2012). Padahal dari sinilah seharusnya pembentukan jiwa sosial, kecerdasan emosional dan spiritual yang sebenarnya.

Kemudian di tengah kemirisan tersebut, masuklah buku-buku dan ajaran modern barat ke Indonesia. Secara tidak langsung buku-buku tersebut "menghipnotis" pemikiran manusia, dan semakin menyamarkan suara hati yang sebenarnya sangat dekat dengan dirinya sendiri. Sesuatu yang tidak terjamah, namun sebenarnya sudah mereka kenal sejak lahir. Suara hati yang bersumber dari Ilahiyah sebagai perwujudan kecerdasan Emosi dan Spiritual dari Sang Pencipta yang tak pernah disadari walau sebenarnya berada sangat dekat dengan dirinya. Menurut Adnan (1998) dalam Sekar Annisa (2012:40), "Hati Nurani akan menjadi pembimbing terhadap apa yang harus ditempuh dan diperbuat." 
Artinya, setiap manusia sebenarnya telah memiliki sinyal-sinyal dalam hatinya sebagai pembimbing dalam segala aktivitas yang dilakukan.

Persoalannya adalah, apakah mahasiswa $\mathrm{S} 1$ jurusan Akuntansi Universitas Lancang Kuning sudah dapat memahami akuntansi dengan sudut pandang spiritual? Karena dengan melibatkan spiritualitas dalam memahami akuntansi, sifat-sifat yang membelenggu suara hati akan melemah dan dapat membawa manfaat bagi kehidupan sosialnya. Dalam penelitian ini saya melakukan studi fenomena pada mahasiswa Jurusan Akuntansi, Fakultas Ekonomi Universitas Lancang Kuning. Saya mengambil beberapa mahasiswa $\mathrm{S} 1$ sebagai informan karena saya menganggap bahwa masa studi $\mathrm{S} 1$ adalah masa yang terpanjang daripada jenjang S2 dan S3, sehingga ilmu pengetahuan yang didapat lebih banyak.

Danah Zohar dan Ian Marshall mendefinisikan kecerdasan spiritual sebagai kecerdasan untuk menghadapi persoalan makna atau value, yaitu kecerdasan untuk menempatkan perilaku dan hidup kita dalam konteks makna yang lebih luas dan kaya, kecerdasan untuk menilai bahwa tindakan atau jalan hidup seseorang lebih bermakna dibandingkan dengan yang lain. Kecerdasan Spiritual adalah landasan yang diperlukan untuk memfungsikan Kecerdasan Intelektual dan Emosional secara efektif. Bahkan kecerdasan spiritual merupakan kecerdasan tertinggi kita (Zohar dan Marshall, dalam Agustian [2005:46]).

Sedangkan menurut Agustian (2005:47), kecerdasan spiritual adalah kemampuan untuk memberi makna spiritual terhadap pemikiran, perilaku dan kegiatan, serta mampu menyinergikan berbagai sudut pandang secara komprehensif. Sudut pandang yang dimaksud dalam penelitian ini adalah sudut pandang Intelektual, Emosional, Spiritual dan Sosial.

Ajaran agama dan ajaran moral mana pun pastilah menjunjung tinggi nilai- nilai kejujuran, ketulusan, rendah hati, menghargai harkat kemanusian, rela berkorban demi kemaslahatan orang banyak, dan semacamnya. Ini juga nilainilai pribadi spiritual yang sifatnya universal, lintas agama dan bersifat langgeng. Artinya melintasi segala zaman dan tempat. Kecerdasan spiritual dalam akuntansi saya mengambil contoh dari contoh penyusunan pelaporan keuangan perusahaan. Jika suatu perusahaan ingin langgeng, pencapaian kebijakan keuangan perusahaan harus menjunjung nilai-nilai yang bersifat langgeng pula, karena hanya dengan cara itu, perusahaan akan bisa selalu menjadi bagian pertanggungjawaban dari nilai pribadi manusia. Kehadiran nilai-nilai spiritualitas akan memainkan peran signifikan dalam proses menjadi kinerja keuangan organisasi yang spiritual, artinya penyusunan laporan keuangan memberikan informasi yang dapat dipercaya dengan segala kebijakan yang ditetapkan. Pencapaian yang akan mampu menghasilkan perubahan sikap individu penyusun laporan keuangan untuk menurunkan praktik penyelewengan dan pelanggaran wewenang (fraud), serta meningkatkan citra atau kredibilitas perusahaan di mata stakeholder (Prasetyo, 2012).

Nilai-nilai spiritual dalam hasil penyusunan pelaporan keuangan akan mampu memberikan ketepatan informasi yang dapat dipercaya bagi seluruh pengguna laporan keuangan tersebut, kehadiran penyusun laporan keuangan yang menumbuhkan kehadiran nilai-nilai spiritualitas akan memberikan dampak bagi perusahaan mampu bertahan dan terus berkembang seperti UPS, Southwest, Starbucks dan Timberland. Sebaliknya, tanpa spiritualitas, perusahaan bisa saja sukses tapi umumnya berjangka pendek, contoh ekstremnya sang raksasa Enron dan WorldCom [Zohar dan Marshall, 2005: 22 dalam Prasetyo (2012)]. 
Pelaksanaan nilai-nilai spiritual penyusun laporan keuangan dalam upaya pemberian informasi kinerja perusahaan, lebih lanjut dibuktikan dalam penelitian Collins dan Porras (1996), menyatakan bahwa atas hasil penelitian yang dilakukan pada akhir tahun 1994 pada 18 perusahaan visioner yang kemudian dibandingkan dengan 18 perusahaan lainnya (yang mewakili perusahaan-perusahaan pada umumnya). Perusahaan-perusahaan visioner, mampu mencapai keberhasilan dalam sukses kinerja keuangan terhadap nilai spiritual penyusun laporan keuangan dengan tingkat yang jauh di atas rata-rata pencapaian semua perusahaan lain (sebesar $87,5 \%$ persen), pada umumnya tidak melakukan pilihan atas dua hal yang kontradiktif. Konsep yang dilakukan dengan upaya penyerasian atau kolaborasi antara keduanya, contohnya mereka tidak memilih sasaran keuntungan jangka pendek untuk mengorbankan sukses jangka panjang, atau mungkin sebaliknya. Namun dengan selalu berupaya untuk sukses dalam jangka pendek dan berupaya pula untuk meraih sukses jangka panjang.

Hasil penelitian Hendricks dan Ludeman (2002), menyatakan bahwa setelah bekerja dengan 800 orang eksekutif dalam 25 tahun terakhir ini, mereka mengajukan sebuah ramalan bahwa para pengusaha yang sukses pada abad ke-21 akan menjadi para pemimpin spiritual. Mereka akan merasa nyaman dengan kehidupan spiritualnya sendiri dan akan tahu cara memupuk perkembangan spiritual orang lain atas hasil informasi pelaporan kinerja keuangan. Mereka meyakini, para pengusaha paling sukses pada zaman sekarang ini, pasti sedikit banyak telah mempelajari rahasia itu.

Aburdene (2006), menyatakan bahwa pelaksanaan nilai-nilai spiritualitas akan menghasilkan nilai-nilai organisasi (value based organization) yang memiliki tujuan tidak semata-mata mencetak profit, tapi harus bisa membawa manusia yang terlibat di dalamnya, baik langsung maupun tidak langsung ke level kehidupan yang lebih baik dengan berusaha menyampaikan informasi keuangan yang mudah dipahami dengan tidak merugikan orang, baik karyawan, pemasok maupun konsumen. Perusahaan yang tidak menumbuhkan nilai-nilai spiritualitas akan menganggap aturan-aturan penyusunan laporan keuangan lebih sebagai tools. Kalau hanya dijadikan tools, bukan values, masih bisa direkayasa, contoh Enron yang memanipulasi laporan keuangannya, dengan dijadikan value akan dijunjung tinggi dan tidak boleh dilanggar (Prasetyo, 2012).

Tirri, Kirsi, Petri Nokelainen dan Martin Ubani (2006) telah menyatukan studi-studi empiris tentang spiritualitas yang dilakukan Hay (1998) dan Bradford (1995) untuk mengukur kecerdasan spiritual, yang terdiri atas 4 dimensi, yaitu:

a. Awareness sensing, yaitu mengacu pada tingkat perhatian seseorang dalam memperhatikan dirinya atau sadar akan kesadaran dirinya.

b. Mystery sensing, yaitu berhubungan dengan kemampuan manusia mentranseden pengalaman sehari-hari dan kemampuan menggunakan imajinasi dalam mentranseden pengalaman sehari-harinya tersebut.

c. Value sensing, yaitu bersinggungan dengan pertanyaan-pertanyaan eksistensial dan pencarian makna.

d. Community sensing, yaitu kemampuan manusia dalam mengaplikasikan kecerdasan spiritual dalam bentuk kepedulian dan tanggungjawab terhadap lingkungan sosialnya.

Tidak ada definisi autoritatif yang cukup umum untuk dapat menjelaskan apa sebenarnya akuntansi itu. Oleh karena itu banyak definisi yang diajukan oleh para ahli atau buku teks tentang pengertian 
akuntansi. American Accounting Association dalam Sumarso (1999) mendefinisikan akuntansi sebagai proses mengidentifikasikan, mengukur dan melaporkan informasi ekonomi, untuk memungkinkan adanya penilaian dan keputusan yang jelas dan tegas bagi mereka yang menggunakan informasi tersebut (Melandy dan Aziza, 2006).

Menurut Suwardjono (2005) pengetahuan akuntansi dapat dipandang dari dua sisi pengertian yaitu sebagai pengetahuan profesi (keahlian) yang dipraktekkan di dunia nyata dan sekaligus sebagai suatu disiplin pengetahuan yang diajarkan di perguruan tinggi. Akuntansi sebagai objek pengetahuan di perguruan tinggi, akademisi memandang akuntansi sebagai dua bidang kajian yaitu bidang praktek dan teori. Bidang praktek berkepentingan dengan masalah bagaimana praktek dijalankan sesuai dengan prinsip akuntansi. Bidang teori berkepentingan dengan penjelasan, deskripsi, dan argumen yang dianggap melandasi praktek akuntansi yang semuanya dicakup dalam suatu pengetahuan yang disebut teori akuntansi (Yuniani, 2010).

Paham dalam Kamus Besar Bahasa Indonesia memiliki arti pandai atau mengerti benar sedangkan pemahaman adalah proses, cara, perbuatan memahami atau memahamkan. Ini berarti bahwa orang yang memiliki pemahaman akuntansi adalah orang yang pandai dan mengerti benar akuntansi.

Melandy dan Aziza (2006), pemahaman akuntansi merupakan suatu kemampuan seorang untuk mengenal dan mengerti tentang akuntansi. Pemahaman akuntansi ini dapat diukur dari nilai mata kuliah yang meliputi Pengantar Akuntansi, Akuntansi Keuangan Menengah 1, Akuntansi Keuangan Menengah 2, Akuntansi Keuangan Lanjutan 1, Akuntansi Keuangan Lanjutan 2, Auditing 1, Auditing 2, Auditing 3, dan Teori Akuntansi. Mata kuliah tersebut merupakan mata kuliah yang di dalamnya terdapat unsur-unsur yang menggambarkan akuntansi secara umum. Dalam hal ini pemahaman akuntansi akan diukur dengan bagaimana mahasiswa mengutarakan pendapatnya mengenai akuntansi jika ditinjau dari sudut pandang spiritual.

\section{METODE}

Adapun jenis dan sumber data dalam penelitian ini adalah data primer dan dan sekunder. Data primer dalam penelitian ini adalah data hasil dari wawancara dengan informan/ responden dalam penelitian ini. Data sekunder penelitian ini diperoleh dengan menggunakan metode tinjauan kepustakaan (library research) dan mengakses website maupun situs-situs.

Mengingat kemampuan peneliti, baik dari segi waktu maupun dana, maka peneliti menggunakan tiga orang mahasiswa Akuntansi S1 semester enam yang menurut saya mempunyai pemikiran yang unik dan berbeda-beda. Pemilihan informan tidak hanya melalui intuisi pribadi semata tetapi juga melibatkan pihak luar (triangulasi informasi), dalam hal ini mahasiswa dan dosen akuntansi.

Untuk memperoleh data yang yang dipergunakan sebagai landasan dalam penelitian maka penulis melakukan pengumpulan data dari lapangan dengan menggunakan observasi, wawancara, dokumentasi dan studi kepustakaan.

Data yang telah berhasil dikumpulkan selanjutnya akan dianalisis secara deskriptif kualitatif, yaitu analisis yang menghasilkan data deskriptif berupa kata-kata tertulis atau lisan dari orang-orang dan perilaku yang dapat diamati dengan metode yang telah ditentukan. Tujuan dari metode ini adalah untuk membuat deskripsi atau gambaran mengenai objek penelitian secara sistematis, faktual dan akurat mengenai fakta-fakta, sifat-sifat serta hubungan antar fenomena yang diselidiki.

Kemudian data tersebut diolah dan dianalisis dengan pola pikir induktif yang berarti pola pikir yang berpijak pada faktafakta yang bersifat khusus kemudian diteliti, dianalisis dan disimpulkan sehingga 
pemecahan persoalan atau solusi tersebut dapat berlaku secara umum.

\section{HASIL}

Informan dalam penelitian ini dipilih berdasarkan pengamatan peneliti terhadap prestasi akademik dan kehidupan sosial informan. Informan dipilih yaitu tiga orang mahasiswa yang memiliki prestasi akademik baik. Prestasi akademik ini dibuktikan melalui nilai mata kuliah yang meliputi Pengantar Akuntansi 1 dan 2, Akuntansi Keuangan Menengah 1 dan 2, Akuntansi Keuangan Lanjutan 1 dan 2, Auditing 1 dan 2, dan Teori Akuntansi.

\section{Pemahaman Akuntansi Dari Perspektif Kecerdasan Spiritual Menurut Informan Pertama: M. Taufik Hidayat}

Menurut Taufik, setiap individu harus menjadikan agama sebagai motivasi berbuat baik dalam semua aktivitas, termasuk dalam profesi akuntansi.

"Menurut saya akuntansi dilihat dari sudut pandang spiritual adalah akuntansi dapat dijadikan motivasi dan dorongan untuk menjadi seorang manusia yang handal dan berguna bagi banyak orang dengan berdasarkan ajaran agama yang dimilikinya."

Dari pernyataan awal Taufik, saya memperoleh signal positif terhadap pemahamannya dari perspektif spiritual. Lalu saya bertanya, bagaimana realisasi dari kesadaran beragama dalam aktivitas seharihari. Taufik memberikan penjelasannya:

"Jadi setiap malam sebelum tidur, saya membiasakan diri untuk berdiam diri, bermuhasabah. Saya introspeksi diri terhadap apa saja yang sudah saya lakukan pada hari itu. Apa yang harus saya perbaiki, apa yang seharusnya saya pertahankan. Apa yang salah di hari itu, agar di hari selanjutnya saya tidak mengulangi lagi. Saya coba untuk memahami suara hatiku, ketika saya melakukan sesuatu apakah hati saya tenang atau tidak. Sudah berapa besar diri saya berguna untuk orang lain hari ini dan sudah berapa orang yang mungkin tersakiti oleh saya secara tidak sengaja."

Kesadaran ini diperoleh karena sudah menjadi kebiasaan dalam kehidupan sehariharinya. Taufik mencoba memahami suara hatinya dan membiasakan diri bermuhasabah setiap hari. Taufik percaya dengan Sabda Rasulullah yang mengatakan sebaik-baiknya manusia adalah mereka yang paling bermanfaat bagi orang lain. Jadi menurut Taufik akuntansi merupakan sebuah alat yang apabila digunakan untuk melakukan kebaikan dan menegakkan kebenaran (dalam pelaporan keuangan) makan akuntansi akan mengantarkan akuntan ke surga. Namun apabila digunakan untuk kebatilan maka akuntansi akan mengantarkan akuntan keneraka.

Abstraksi yang dapat saya buat dari diskusi dengan Taufik adalah, kesadaran beragama dalam segala aktivitas didapatkan Taufik dari hasil refleksi pengalaman ibadahnya sehari-hari. Implikasinya adalah seharusnya memahami akuntansi disertai dengan kesadaran beragama agar mahasiswa akuntansi mempunyai karakter spiritualis, yang bertindak berdasarkan nilai-nilai spiritual yang luhur. Taufik menyayangkan bahwa sistem yang berlaku di Indonesia menjadi penghambat untuk merealisasikan kesadaran beragama tersebut, sehingga dibutuhkan keyakinan yang kuat untuk merubahnya. Perubahan sistem menurut Taufik bukanlah hal yang mudah dan tidak bisa dilakukan sendiri, tetapi membutuhkan orang yang banyak dan waktu yang tidak sebentar agar sistem dapat berubah.

\section{Pemahaman Akuntansi Dari Perspektif Kecerdasan Spiritual Menurut Informan Kedua: Safitri Rezki Maharani}

Menurut pernyataan awal Fitri, Akuntansi yang seharusnya diterapkan adalah akuntansi yang berlandaskan agama. "Menurut Fitri, semua hal harus dikaitkan dengan spiritual, karena bagi Fitri pribadi yang memang sedang dalam proses belajar mendalami ajaran-ajaran agama, akuntansi yang lebih bagus itu ya akuntansi yang berdasarkan agama, karena kita semua punya kepercayaan dan apa yg diajarkan di agama kita masing-masing itu pasti hal baik, akan lebih baik jika akuntansi 
berlandaskan agama, menurut Fitri kalau akuntansi sudah berlandaskan agama, maka seorang akuntan atau profesi apapun bukan hanya sekedar alat, tapi lebih dari itu"

Fitri yang sudah saya kenal lebih kurang selama 4 tahun adalah pribadi yang agamis dan pintar. Tidak heran jika sedang membahas mengenai spiritualitas, pendapatnya selalu menarik. Kemudian Fitri menjelaskan pernyataannya terkait profesi akuntan.

"Disini akuntan itukan bekerja sesuai dengan ketentuan atau aturan yg berlaku, kembali lagi ke aturannya, tidak semua aturan memang bertentangan dengan kaidah agama, cuma masih banyak unsur riba juga kan bu. Misalkan aturannya sesuai kaidah agama, pahala mengalir kepada akuntan tersebut, tapi jika aturan yang diikuti tidak mengikuti kaidah agama, dosa yang mengalir bu"

Diskusi saya lanjutkan dengan bertanya apakah seorang akuntan dapat masuk surga atau tidak.

"Kalau menjamin masuk surga kembali ke pribadi dan ketaatan kita masing-masing menurut Fitri, soalnya kan kalau pun kita menjalankan praktik akuntansi sesuai syariat agama sedangkan perilaku kita banyak menyimpang dari ajaran agama, tetap saja kita berdosa bu. Tapi juga, jika kita menjalankan kehidupan kita sesuai kaidah agama. Sedang dalam praktik kerja akuntansi kita melenceng dari syariat islam, contohnya riba, itu kan dosa besar bu, alangkah lebih baik semua kegiatan kita diiringi dengar spiritual, agar diridhoi Allah, yaa nantinya juga yg menilai kembali juga Allah bu"

Pendapat Fitri hampir sama dengan yang diutarakan Taufik mengenai sistem. Aturan yang dimaksud Fitri merupakan sistem yang dibuat manusia yang telah mengakar dan membudaya, sehingga mau tidak mau manusia harus menjalankannya. Permasalahannya, apakah sistem atau aturan tersebut sesuai dengan ketentuan Tuhan? Realitanya, seperti yang dijelaskan Fitri, memang tidak semua aturan bertentangan dengan ketentuan Tuhan, tetapi beberapa ada yang tidak sesuai. Hamba Tuhan, dalam diskusi ini yang dimaksud adalah akuntan, dapat masuk surga atau tidaknya hanya Tuhanlah yang berhak menentukan. Yang dapat dilakukan manusia adalah menentukan, apakah akan berperilaku sesuai dengan ketentuan Tuhan atau tidak. Dari situlah, dapat diperkirakan konsekuensinya apakah berbuah manis atau tidak.

Abstraksi yang dapat saya buat dari studi fenomenologis berdiskusi dengan Fitri adalah, Fitri sudah memiliki kecerdasan spiritual sehingga dapat memahami akuntansi berlandaskan agama. Poin plusnya adalah, Fitri memiliki keyakinan yang kuat untuk merubah sistem yang ada dengan mengusahakan perubahan semampu yang dia bisa. Caranya adalah melalui diskusi dengan teman-temannya, lalu "mempengaruhi" lawan bicaranya dengan pemikiran yang positif. Menurut Fitri, cara ini memang tidak dapat diberlakukan secara menyeluruh, tapi mengusahakan perubahan dari hal yang kecil merupakan kesadaran yang direalisasikan dalam bentuk gerak yang nyata.

\section{Pemahaman Akuntansi Dari Perspektif Kecerdasan Spiritual Menurut Informan Ketiga: Sahrul Darmawansyah}

Saya bertanya kepada Sahrul, bagaimana menurutnya ketika akuntansi dikaitkan dengan faktor Spiritual. Sahrul menjawab:

"Kalau menurut arul, akuntansi adalah ilmu yang menghargai masa lalu. Dikarenakan pencatatan dan bukti serta transfer disimpan dan dicatat sebagai bukti untuk masa depan"

Kecerdasan spiritual tampak pada informan ketika sedang berdiskusi dengan saya, dan itu ditunjukan dengan ketegasannya menjawab pertanyaan yang saya berikan terkait akuntansi dan spiritual. Lalu saya bertanya lagi, apakah menurutnya akuntan dapat masuk surga atau tidak.

"Bisa bu, karena indikator untuk masuk surga bukan karena profesi seseorang. Tapi perilaku akuntan sekarang menurut sahrul masih belum sepenuhnya menjadikan 
agama sebagai pondasi mereka dalam mengambil keputusan."

Menurut Sahrul, tidak selamanya profesi akuntan itu dikonotasikan dengan hal negatif. Tetapi potret buram profesi akuntan yang negatif dapat dibersihkan kembali dengan berbuat lebih banyak kebaikan dalam kehidupan sehari-hari. Berusahalah agar menjadi akuntan yang baik, yang mempunyai moral dan etika yang baik. Sahrul meyakini bahwa manusia yang melakukan lebih banyak kebaikan daripada keburukan akan masuk surga, begitu pula dengan profesi akuntan.

Berdasarkan studi fenomenologis saya berdiskusi dengan Sahrul, yang dapat saya abstraksikan adalah Sahrul sudah dapat memahami akuntansi dari sudut pandang spiritual dengan mematuhi ajaran agamanya, mengusulkan akuntansi berlandaskan agama agar dapat melahirkan akuntan yang memiliki moral baik. Pendapat Sahrul mengenai konsep surga dan neraka dengan profesi akuntan menurut saya dapat dikaitkan dengan konsep utilitarian, yaitu menekankan pentingnya konsekuensi perbuatan dalam menilai baik atau buruknya kualitas diri seseorang. Konsekuensi perbuatan manusia menentukan seluruh kualitas moralnya, begitupun dengan para pelaku akuntansi

\section{PEMBAHASAN}

Seseorang mempunyai pendapat dan pemahamannya masing-masing dalam memaknai akuntansi. Setiap pendapat dan pemahaman tersebut adalah konsep yang akan dapat dibentuk oleh seseorang melalui ilmu pengetahuan dan pengalaman. Apa yang dipahami oleh masing-masing individu didasari oleh suatu nilai yang mereka yakini benar. Akuntansi adalah ilmu yang sarat akan nilai, akan tetapi nilai apa yang setiap individu yakini benar, kembali lagi kepada bagaimana caranya menyaring ilmu yang mereka pelajari. Ketika pendidikan akuntansi tidak bebas nilai, tetapi sarat nilai, otomatis akuntansi konvensional yang saat ini masih didominasi kapitalisme Barat, maka karakter sistem pendidikan akuntansi pasti kapitalistik pula (Mulawarman, 2006). Menurut saya, akuntansi kapitalistik identik dengan rasionalitas. Rasionalitas berkaitan dengan konsep sebab-akibat, atau dikenal dengan etika Utilitarisme.

Menurut Bertens (2000:66), utilitarisme sebagai teori etika cocok sekali dengan pemikiran ekonomis. Teori ini cukup dekat dengan cost-benefit analysis yang banyak dipakai dalam konteks ekonomi. Manfaat yang dimaksud bisa dihitung sama seperti menghitung untung dan rugi dalam konteks bisnis. Pemikiran rasional merupakan produk kecerdasan intelektual yang terkait dengan hal-hal yang fisikal, eksoteris dan bentuk (form). Kecerdasan intelektual menjadi kuasa yang luar biasa kuat pengaruhnya bagi kehidupan manusia karena merupakan modal satusatunya untuk membangun pengetahuan (Triyuwono, 2007). Padahal intelektual bukanlah kecerdasan yang maha tunggal. Masih ada kecerdasan-keserdasan lain yang lebih tinggi dibandingkan kecerdasan intelektual. Menurut saya, adalah suatu pemahaman yang salah jika para insan pendidikan hanya terpaku pada kemanunggalan intelektual. Akibatnya, pemahaman yang dihasilkan pun juga berpusat pada satu sumber. Disadari atau tidak kecerdasan intelektual sebetulnya telah melakukan penindasan terhadap sistem pendidikan dan akhirnya juga pada jati diri peserta didik (Triyuwono, 2007).

Dalam penelitian ini, hampir semua informan mengharapkan agar akuntansi berdiri di atas pondasi nilai-nilai spiritual yang kokoh, dalam hal ini akuntansi yang berlandaskan agama. Menurut saya, ketiga informan sudah mempunyai kesadaran spiritual yang sangat baik.

Hampir seluruh pemahaman akuntansi informan dari berbagai sudut pandang diperoleh dari proses belajar selama perkuliahan. Pendidik mempunyai peran yang penting dalam pembentukan pemahaman mahasiswa. Sebelum mengeksplorasi kecerdasan mahasiswa, para pendidik harus menyadari bahwa pendidikan adalah upaya untuk menyatukan berbagai kecerdasan agar mencapai 
pendidikan yang seimbang. Sebagaimana dikutip dari Kamayanti (2012), yaitu "before a lecturer could help students realizing their holistic full competencies, they must at first be consciuous of their own."

Sebelum mahasiswa disadarkan dengan kecerdasan holistik mereka, para pendidik seharusnya mempunyai kesadaran dalam dirinya terlebih dahulu agar dapat membantu mahasiswa dalam mencapai pemahaman akuntansi. Pemahaman yang dimaksud dalam penelitian ini adalah pemahaman yang menyatukan berbagai kecerdasan yaitu kecerdasan emosional, spiritual dan sosial. Untuk itulah peran dari para pendidik akuntansi, terutama kesadaran mereka sangatlah penting. Chandra et al dalam Kamayanti (2012) menjelaskan bahwa: Dengan kata lain, salah satu kesuksesan dalam pendidikan akuntansi dicapai dengan meningkatkan kesadaran para pendidiknya. Selain itu, metode pembelajaran yang digunakan oleh pendidik juga mempunyai pengaruh yang besar terhadap pemahaman dan paradigma mahasiswa. Taufik memahami akuntansi didominasi oleh kecerdasan emosionalnya yang didapat dari perkuliahan yang dibimbing oleh sosok pendidik yang dikenal berparadigma interpretif dengan metode pembelajaran menggunakan olah rasa dan olah batin. Fitri memahami akuntansi dengan kritis dan berlandaskan agama diperoleh dari perkuliahan yang dibimbing oleh sosok pendidik yang dikenal berparadigma kritis spiritualis dengan metode pembelajaran diskusi dan refleksi batin spiritual. Sahrul memahami akuntansi secara rasional berdasarkan textbook diperoleh dari kenyamanannya mengikuti perkuliahan oleh sosok pendidik yang metode pembelajarannya dikenal dengan ceramah dan pemberian tugas secara intensif.

Beberapa metode pembelajaran harus dikolaborasikan dan ditransformasikan menjadi metode dialogis untuk menciptakan hubungan horizontal antara orang-orang yang terjalin dalam komunikasi tersebut. Hal ini dilakukan agar pemahaman akuntansi mahasiswa diperoleh dengan cara yang sangat lembut. Walaupun penelitian ini mengklarifikasikan kecerdasan dari sudut pandang Spiritual, namun sebenarnya yang dimaksud dengan kecerdasan adalah kecerdasan yang utuh, yaitu sadar diri, spiritual, dunia dan alam semesta. Kecerdasan tidak hanya dipandang dari intelegensia saja tetapi juga mengintegrasikan seluruh kecerdasan lainnya. Keseluruhan kecerdasan tidak hanya diintegrasikan untuk kepentingan pribadi semata, tetapi juga harus dipancarkan untuk peradaban.

\section{SIMPULAN}

Kesimpulan yang diamabil menunjukkan bahwa pemahaman mahasiswa mengenai akuntansi jika dilihat dari kulit terluarnya memang masih didominasi oleh kecerdasan intelektualnya. Tetapi setelah saya memperdalam proses diskusi, dapat dilihat bahwa informan dapat memahami akuntansi dari sudut pandang spiritual.

Karakter mahasiswa mempengaruhi pola pikir mereka, termasuk dalam memahami akuntansi. Ketiga informan dalam penelitian ini mempunyai karakter yang berbeda-beda sehingga pemahaman akuntansi merekapun berbeda. Karakter Taufik yang penyabar dan tegas membuatnya memahami akuntansi dengan dominasi emosional yang baik. Fitri yang sudah saya kenal adalah orang yang religius, penyabar, kritis dan berjiwa sosial, sehingga Fitri dapat memahami akuntansi dengan kecerdasan spiritual. Sahrul adalah mahasiswa yang pintar, aktif dan berprestasi di bidang akademik. Karakter tersebut membuat Sahrul memahami akuntansi didominasi oleh kecerdasan intelektualnya.

Hampir seluruh pemahaman akuntansi informan diperoleh dari pengalaman mereka selama proses perkuliahan. Semua informan merupakan mahasiswa Akuntansi S1 pada saat proses wawancara dilakukan. Pada saat itu hampir seluruh mata kuliah akuntansi telah mereka tempuh sehingga menurut saya, mereka 
sudah memahami akuntansi dengan baik. Selain dari proses belajar saat kuliah, pemahaman akuntansi juga diperoleh dari pengalaman spiritual dan sosial mereka masing-masing. Pengalaman spiritual berupa kebiasaan beribadah rutin dan mematuhi ajaran-ajaran dalam agama. Sedangkan pengalaman sosial adalah bagaimana setiap informan berinteraksi dalam kehidupan masyarakat, juga kepedulian terhadap masyarakat dan lingkungan di sekitarnya.

Berdasarkan temuan yang sudah saya bahas sebelumnya, ada beberapa saran untuk mengupayakan adanya perubahan dalam pendidikan akuntansi, diantaranya adalah: Diharapkan agar mahasiswa dalam memahami akuntansi dapat mengintegrasikan segala sudut pandang kecerdasan agar dapat mencapai keseimbangan dalam proses pembelajaran. Secara umum saya berharap agar institusi mendukung dan memfasilitasi pendidikan akuntansi yang mengintegrasikan berbagai macam kecerdasan dalam proses belajar mengajar. Secara khusus saya tujukan kepada para pendidik akuntansi agar mengkolaborasikan berbagai metode dan paradigma dalam membimbing perkuliahan untuk mempersiapkan calon-calon akuntan yang dapat bermanfaat bagi peradaban. Harapan saya penelitian ini dapat memberi wawasan pada masyarakat luas bahwasanya banyak cara yang dapat ditempuh agar dapat memahami suatu ilmu, tidak hanya dari satu sudut pandang saja tetapi dari berbagai macam.

\section{DAFTAR RUJUKAN}

Agustian, Ary Ginanjar. 2005. Rahasia Sukses Membangun Kecerdasan Emosi dan Spiritual ESQ: Emotional Spiritual Quotient The ESQ Way 165: 1 Ihsan, 6 Rukun Iman dan 5 Rukun Islam. Jakarta: Penerbit Arga.

Ekasari, Kurnia. 2012. Internalisasi NilaiNilai Pancasila dalam Pendidikan Akuntansi. Prosiding Konferensi Nasional Pendidikan Akuntansi
Indonesia, Jurusan Akuntansi FEB Universitas Brawijaya \& IAI KAPd.

La'lang, Aprianto dan Kuddy. 2010. Menanam Prinsip Ketuhanan: Menuai Keseimbangan Dalam Pendidikan Akuntansi. Jurnal Ilmiah. (Online), (www.google.com, diakses pada tanggal 27 Juli 2012).

Melandy, Rissyo dan Nurna Aziza. 2006. Pengaruh Kecerdasan Emosional terhadap Tingkat Pemahaman Akuntansi, Kepercayaan Diri sebagai Variabel Pemoderasi. Jurnal Ilmiah. Simposium Nasional Akuntansi 9 Padang.

Mulawarman, Aji Dedi. 2012. Pendidikan Akuntansi Indonesia: Pro Neoliberal atau Pancasila?. Prosidig Konferensi Nasional Pendidikan Akuntansi Indonesia, Jurusan Akuntansi FEB Universitas Brawijaya \& IAI KAPd.

Prasetyo, Whedy. 2012. Perbedaan Persepsi Nilai-Nilai Spiritualitas Pelaku Akuntansi (Manajer dan Praktisi) terhadap Akuntansi Kreatif. Prosidig Konferensi Nasional Pendidikan Akuntansi Indonesia, Jurusan Akuntansi FEB Universitas Brawijaya \& IAI KAPd.

Yudhi, Riswan dkk. 2012. Pengaruh Kecerdasan Emosional Dan Kecerdasan Spiritual Mahasiswa Akuntansi Terhadap Tingkat Pemahaman Akuntansi. Jurnal Ilmu-Ilmu Sosial (Socioscientia). Vol. 4, No. 2 Juni 2012 Hl. 187374. ISSN 2085-5494.

Sekar, Annisa Mulia, 2012. Mengungkap Pemahaman Tentang Akuntansi 
Dari Sudut Pandang Kecerdasan Emosional, Spiritual Dan Sosial Mahasiswa, Jurnal Akuntansi Multiparadigma Jamal Vol. 3, No. 3 Hal. 334-501, Malang, Desember 2012, ISSN 2086-7603

Setiawan, Achdiar Redy dan Ari Kamayanti. 2012. Mendobrak Reproduksi Dominasi Maskulinitas dalam Pendidikan Akuntansi: Internalisasi Pancasila dalam Pembelajaran Accounting Fraud. Prosiding Konferensi Nasional Pendidikan Akuntansi Indonesia, Jurusan Akuntansi FEB Universitas Brawijaya \& IAI KAPd.

Triyuwono, Iwan. 2010. Perspektif, Metodologi, dan Teori Akuntansi Syariah. Jakarta: Rajawali Press. 